\title{
ANALYSIS OF CONTENT TYPE OF DYE IN KEMBANG GOYANG TRADITIONAL SNACK IN SUBAGAN VILLAGE
}

\author{
Anak Agung Ketut Alit Pujawan \\ aalitpujawan@yahoo.com \\ Sekolah Tinggi Pariwisata Nusa Dua Bali
}

\section{ABSTRACT}

Esteemed for its culture, Bali has developed as a cultural based tourism destination. Traditional food is part of the Balinese culture and is the one of some tourism attribute in Bali. Through the traditional snack or commonly called as "JajananPasar", the local community of Subagan Village which is a small village in Bali tries to make a commodification their Kembang Goyang traditional snack for the purpose to add economic value as a tourism product. Seeing these ongoing developments, this study to analyse the content of food dye that contained in KembangGoyang Traditional Snack of Subagan Village. This research to stress an aspect of the type of food dye is used in Kembang Goyang Traditional Snack which is related to food safety. As one of tourism product, this issue is crucial and quite essential to be researched. Using qualitative descriptive, this research was conducted by implementing in-depth interview and observation. The method of analysing qualitative descriptive data in a study is useful to develop a theory that has been built from the data that has

Keywords: Traditional Snack, Synthetic Dye, Commodification, Kembang Goyang.

\section{INTRODUCTION}

Kembang Goyang Traditional Snack is one of most Indonesiantraditional snack which is originally came from Betawi. It is made from rice flour, this traditional snack has spread out and was getting thrive in one region to another region in Indonesia especially in Bali. Balinese local community who believe in Hindu, KembangGoyang used to be an offering in any Hindu's Ceremony. The name of Kembang Goyang was taken from the shape of Kembang Goyang itself. The shape of Kembang Goyang is more likely to a flower, and flower in Indonesia is commonly known as "Kembang".

Moreover, the term of "Goyang" was taken from the method of cooking Kembang Goyang itself, the method of cooking of Kembang Goyang is shaking (in Indonesian most known as "Goyang") to the mould in purpose that the batter detached from the pattern. The ingredients for making Kembang Goyang are so easy to find, such as; Egg, Castor sugar, rice flour, coconut milk, grated coconut, and frying oil. The first step that has to do is beat the egg with caster sugar until snow stiff. Then, pour in the flour which has been sieved, fold in. Then pour in the coconut milk and pinch of salt. The incorporate batter must stir until it was well combined, the last step is frying (KueNusantara, 2014).
Based on data that researcher obtained through depth interview directly to the seller, the number of selling of KembangGoyang snack in every seller in Subagan Village undergo enhancement on a particular day. On average, sell of kembangGoyang on an average day up to Rp. 195.833,- whereas on a special day the selling of KembangGoyang is higher than the average day up to Rp. 547.917,-. Therefore KembangGoyang still has a high demand in the local community and Tourist. It can be seen from some selling. If understand it as a percentage, the number of sale of Kembang Goyang in Special Day is increasing up to $64 \%$. Exposure regarding some selling of KembangGoyang in Subagan Village can be seen in table 1.1 below;

In table 1.1 shows that the averageof selling is more than $60 \%$, that number implies the potential of Kembang Goyang snack is big enough. Based on an interview with one of some Kembang Goyang sellers in Subagan Village, the customer who buys Kembang Goyang traditional snack in Subagan Village are Tourist. It can be seen from some selling. If understand it as a percentage, the number of sale of Kembang Goyang in Local community and tourist who visit Subagan Village, whether it is an international tourist or domestic tourist.

Table 1.1

KembangGoyang Selling in DesaSubagan (In Rupiah)

\begin{tabular}{|r|l|c|c|c|c|c|c|c|c|}
\hline \multirow{2}{*}{ No } & \multirow{2}{*}{ Seller } & \multicolumn{7}{|c|}{ Selling per Month } & \multicolumn{2}{c|}{ Increase / Decrease } \\
\cline { 3 - 10 } & & $\begin{array}{c}\text { Normal } \\
\text { Day }\end{array}$ & Unit & QTY & Unit & $\begin{array}{c}\text { Special } \\
\text { Day }\end{array}$ & Price & Total & Percentage \\
\hline 1 & Tut Mudiasih & 20 & Pack & 100,000 & Pack & 45 & 225,000 & 125,000 & $56 \%$ \\
\hline 2 & $\begin{array}{l}\text { Tut Padma } \\
\text { Wati }\end{array}$ & 50 & Pack & 250,000 & Pack & 100 & 500,000 & 250,000 & $50 \%$ \\
\hline 3 & Haeriah & 60 & Pack & 300,000 & Pack & 200 & $1,000,000$ & 700,000 & $70 \%$ \\
\hline 4 & Rusmini & 20 & Pack & 100,000 & Pack & 50 & 250,000 & 150,000 & $60 \%$ \\
\hline 5 & NengahKantun & 40 & Pack & 200,000 & Pack & 250 & $1,250,000$ & $1,050,000$ & $84 \%$ \\
\hline 6 & Budiasih & 40 & Pack & 200,000 & Pack & 200 & $1,000,000$ & 800,000 & $80 \%$ \\
\hline 7 & Wayanmariati & 30 & Pack & 150,000 & Pack & 80 & 400,000 & 250,000 & $63 \%$ \\
\hline 8 & Ekaagustini & 20 & Pack & 100,000 & Pack & 50 & 250,000 & 150,000 & $60 \%$ \\
\hline 9 & DavuLilik & 60 & Pack & 300,000 & Pack & 80 & 400,000 & 100,000 & $25 \%$ \\
\hline 10 & Bu Sumiati & 60 & Pack & 300,000 & Pack & 100 & 500,000 & 200,000 & $40 \%$ \\
\hline 11 & Riska & 50 & Pack & 250,000 & Pack & 100 & 500,000 & 250,000 & $50 \%$ \\
\hline 12 & NengahCandra & 20 & Pack & 100,000 & Pack & 60 & 300,000 & 200,000 & $67 \%$ \\
\hline Selling Average & & & 195,833 & & & $\mathbf{5 4 7 , 9 1 7}$ & $\mathbf{3 5 2 , 0 8 3}$ & $\mathbf{6 4} \%$ \\
\hline
\end{tabular}


Some seller in Subagan Village also offer to the tourist how to make Kembang Goyang, and the tourist can involve directly how to make it. The tourists who visited that village do not only enjoy KembangGoyang but also can get valuable experience through something to learn and in the end, will give a different experience when the visit to Subagan Village hence their money that they spent on it will be value for money.

To increase the appearance of KembangGoyang traditional snack, the sellers in Subagan Village have done a commodification to KembangGoyang snack. The commodification that applies to KembangGoyang snack is adding color so that the appearance of KembangGoyang more attractive as a tourism product. Adding colour to KembangGoyang makes those snacks have more variety of colour, automatically it will give value added to KembangGoyang, and it will give economic benefit as well. Based on data that researcher obtained, the researcher did an observation to Traditional snack sellers in Subagan Village and found out KembangGoyang which used to has a brown colour, but now it sells in various colours are red, yellow, green, orange and so on. Reviewed on that circumstance and data that researcher obtained in advance drives researcher to do research related to food dye which is being applied into Kembang Goyang Snack in Subagan Village, type of food dye that the researcher will research is related to synthetic dye and natural dye.

Nowadays, many producers of food misuse of colour on food. To get high profit, the sellers use synthetic colour on the food; it is cheaper and accessible to find out the cause. Misuse of colour on food is driven by a limitation of natural dye on the market, and durability of natural dye is not as excellent as synthetic colours and will give an impact to the longevity of KembangGoyang. The lacking of natural dye is low pigment stability and poor colour uniformity in food. In addition, the lack of public understanding of dyes is also a factor of misuse of dyes, for example, the use of synthetic dyes for food that is used excessively, as well as colouring agents for textiles and leather are sometimes used to colour food ingredients (NurHidayat, 2006). This is very dangerous for health because of the presence of heavy metal residues in the textile and leather colouring agent. Regulations concerning the use of dyes that are permitted and prohibited for food are regulated by the Decree of the Minister of Health of the Republic of Indonesia No. 722 / Menkes / IX / 88 concerning food additives.

Research technique is used on this research is descriptive qualitative analyse data technique. Qualitative research studies investigation with data be avowed into verbal and be investigated without any statistic technique (Etta Mamang S. and Sopiah, 2010). Descriptive qualitative analyse method in research has a utility to build theory from data have been obtained in the field. Qualitative research method on the first step is to do an exploration into the research field, and then collect data until getting crucial data, observation and preparation of the report from data that has been received.

In this research, the variable that would be stressed is KembangGoyang which sell in Subagan Village, Karangasem. Samples of KembangGoyang which have been taken will be tested in Laboratory using Chromatography test technique. Chromatography is a technique to separate the mixture into a component with differentiation of physic nature assisted in each element. The tools are used consist of the column inside is filled by fasatasioner (solids or liquid). The mixture added into the column from one tip and mixture will move with suitable bearer assisted (mobility phase). Separation is achieved by the difference in the rate of decline of each component in the column, which is determined by the adsorption force or partition coefficient between the mobile phase and stationary phase (Takeuchi Yoshito, 2009). The chromatography method that will be used in this research is the Paper Chromatography Method. Martin and Synge discovered this method in 1943, which for the first time separated and identified plant constituents. Paper chromatography is an analytical method used to separate coloured chemicals, especially pigments (Haslam, 2007).

In other hands, in this research also using descriptive qualitative analyse technique, that is data in information form,

described, and then linked - related to other data to get a new description and more clearly (sugiyono (2005; 13). The information the researcher got about commodification and the development of KembangGoyang snacks in the tourism industry is outlined and given a review based on the existing theories and described in a detailed and in-depth narrative so that a clear description of commodification and development of KembangGoyang Snacks in the tourism industry is obtained.

\section{LITERATURE STUDY}

\section{Food Commodification}

In this level, beautiful food is not just occurring a transformation, but also commodification value. Barker (2005;

517) stated that commodification is a result of the association of process above capitalism. There are some modifications to the object and quality of the object and changed to be a commodity. The commodity correlates with market and sales. In the explanation above, we can take the assumption that commodification is the result of the production of the working process which has a different function from the original function. It is more likely to create sell and buying value. Whether the statement of Barker, Smith or Evans affirm that there is a more significant concept, thank value exchange, but selling and buying. Aesthetic food is the primary concern to

make it be the commodity.

The application of beautiful food is associated with the exchange process. Revolution and additions occur to the value of the food itself. When commodification of food gradually becomes a commodity, which initially does not pay attention to the appearance of food, but since the commodification has applied on it, the presence of food would be as a primary concern to make it as a valued commodity. It can be explicitly seen that the commodity formation process has taken place. However, in its current development, it turns out that it is not only an exchange of food and value for money, there is a new context that mingles and combines in these foods, namely art. Food with artistic value has a higher value, and this is used as a commodity in the global food industry now.

\section{Traditional Snack}

Traditional snack is a snack that made through the conventional method and traditional ingredients, while the term of Jajanan has meant that food maker produces food or beverages in the place where they sell food, so the food is ready to eat and of course prepared to sell to the customer (JurnalllmuGizi, 2014). 
According to Winarno (1994) "for making a traditional snack, we have to know the first type of base ingredients quality of ingredients will use". The grouping of ingredients for making traditional Indonesian snacks is different from the ingredients for making continental snacks or Asian snacks or modern snacks. The ingredients for making traditional Indonesian snacks can be classified as essential ingredients, liquid ingredients, flavour enhancing ingredients, colours and aromas, and other ingredients. Each of these ingredients requires special handling techniques. The accuracy of the selection of ingredients significantly affects the cake produced. The material composition generally consists of tubers, flour (rice, sticky rice, sago, flour), coconut milk, and sugar. While the salty uses a variety of meat, fish, chicken, and others. Some products are processed using cooking oil. The material used is adapted to natural products from the area, generally using fresh ingredients without being processed.

\section{KembangGoyang Snack}

KembangGoyang snack is a traditional snack originally came from Betawi which still has high demand in the community. This snack is made from rice flour. Some cities, KembangGoyang snack, offer when a particular day has come. The name of KembangGoyang" came from the shape like a flower (Kembang) and the method of cooking is shaking (Goyang) until the batter detached from the mould (e-journal Boga, Vol 5 No. 3, 2016). KembangGoyang was most known as a snack not as the main dish in the community. In Trenggalek, Jawa Timur, KembangGoyang is called as Matahari, meanwhile, in Blitar city, this snack is called matari. The term "Matahari" is a result of interpretation of community that KembangGoyang shape like a sun. The mould of KembangGoyang has become a uniqueness of this snack, and the mould shape is like a flower (Kembang). The frame of KembangGoyang is made from old iron and thick. Before using the mould, it should be heated first.

Kembang Goyang snack commonly served on the big day of ceremony like Idul Fitri Ceremony, Wedding Ceremony, or as a souvenir because has good appearance and taste. Basics ingredients of making Kembang Goyang is rice flour, tapioca, egg, sugar, salt, and heavy coconut milk. From those ingredients, we know that nutrient value of Kembang Goyang Snack per 100 grams is $51,88 \%$ carbohydrate, $5,18 \%$ protein, $2,36 \%$ tissue, 0,11 mg Vitamin B15, 1,1 mg Vitamin E, and 241,8 kcal energy (Balai Penelitian dan Konsultasi Industri

(BPKI), 2016).

In general, the functional criteria of KembangGoyng snack involve colour, fragrant, taste and texture. The colour of KmbangGoyang generally is yellow or brown, but nowadays there are varieties of colours. In taste aspect originally is not too sweet and tend to flavourless, and has unique fragrant. Moreover, for texture itself should be crispy and dry.

\section{Food Color/dye}

Food colouring is a food additive that can improve food appearance to be attractive, homogenise and stabilize colours, and cover colour changes due to processing and storage (Cahyadi, 2009). According to Permenkes RI No.722 / Menkes / Per / IX / 1988, colouring agents are food additives that can improve or colour the food.

\section{RESULT}

\section{Food Safety of KembangGoyang Snack}

There were 12 sellers of traditional snack in Subagan Village that researcher has visited, among ten from 12 sellers are located in Karangsokong traditional market in Suabagan village. Moreover, two other sellers have their shop which in each located in Nenas Street and Gunung Agung Street, Subagan Village. The author only chooses two sellers from Karangsokong traditional market as an object of research, because most of KembangGoyang that they sell in the market has the same supplier. For another two sellers author choose the sellers who have their shop and of course they produced KembangGoyang by themselves. In Total, the researcher took

four sellers as an object of research. Here is the result of data has been obtained and has been tabulated that a purpose of this research of KembangGoyang in Subagan Village;

Table 1.2

Chromatography Laboratory Test of KembangGoyang Traditional Snack

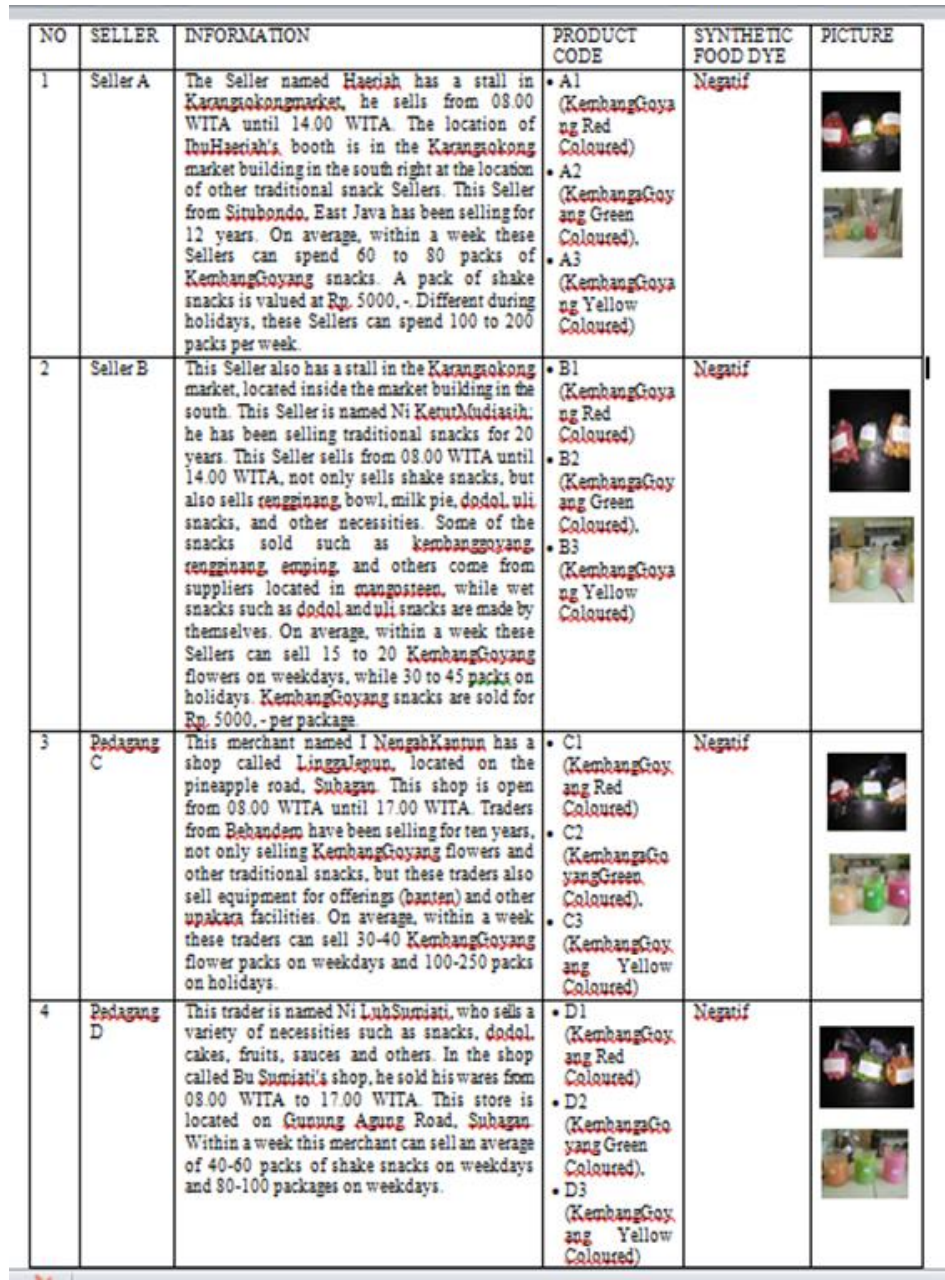

Source: Laboratory Test 2018 
Negative result is obtained from this Kembang Goyang snack study showed samples of A, B, C, and D using natural dyes instead of artificial coloring both artificial coloring for food and artificial coloring which is not for food, because if using artificial colouring or synthetic colour the sample would still have adhered to woollen yarn even though it has been washed clean and will be continued with the next steps, namely by separating the colour that is still attached to the thread. It is also known that the natural dyes used come from plants, such as red in samples A, B, and D obtained from the red colour on rosella flowers and sample $\mathrm{C}$ uses beet tuber. The green colour of the three examples is obtained from Suji leaves with different colour usage or concentration, while the yellow colour in sample $\mathrm{A}$ and the orange colour of the samples B, C, and D are obtained from turmeric and carrots.

\section{The commodification of Kembang Goyang as Tourism Product.}

The existence of culinary in nowadays has considered as the important things, especially in the tourism sector. The presence of culinary at this moment has acknowledged as part of the tourism industry, the establishment of the restaurant in the hotel business became an indicator that culinary has a significant contribution to income after room revenue. The expert also already take the culinary into account, that tourists who do travelling do not only need room for stay but need food as well. See this prospect, culinary now in the tourism sector is being an attribute of tourism that able to attract tourist to visit, and culinary also has significant potential and a substantial contribution to the tourism sector.

Culinary tourism is a journey that includes activities to consume local food from an area; travel with the primary objective is to enjoy food and drinks and or visit a culinary movement, such as cooking school, visit the centre of the food and beverage industry; and to get a different experience when eating food and drinks (www.digilib.petra.ac.id). Then what about Kembang Goyang Traditional Snack? The development of culinary and develop tourism in Bali, much traditional or culture has occurred commodification.

Currently, Kembang Goyang snacks have experienced various commodification to add economic value as a tourism product. Although the potential of Kembang Goyang as a tourism product is quite good, Subagan villagers tried to enhance the potential of these snacks as products that are used as tourism products. The commodification that occurred in traditional KembangGoyang snacks is in the appearance of the snack. Initially, the snacks were golden yellow or yellowbrown, now it has changed, the Sellers in Subagan Village added a variety of additional colours, so the colour variations in this product have various tone. Not only on appearance, but commodification of traditional Kembang Goyang snacks also occurs on taste and aroma. The feeling of KembangGoyang snack initially taste a little sweet, now the size of sugar is using in this snacks is added to add sweetness to the snacks. The scent of KembangGoyang snacks is also sharpened, the addition of artificial aromas is also given to this product so that with the acquisition it can increase the appetite of consumers for these snacks. There are also indications of commodification in KembangGoyang snacks on the transition of function, in the old time this snack is used to use as an offering and also as consumption of local people. Meanwhile, Kembang
Goyang'sfunction has changed as a tourism product which is given economic value.

In general, the commodification of Kembang Goyang is good, in nowadays the people in Bali, especially for youth in Bali is getting leave the old culture included KembangGoyang. Also, the commodification indirectly will help to revitalise the culture and preserve the culture stay conserved.

In culinary commodification, there is a transformation or culinary value as a food processing as a fulfilment of primary needs in human life into a culinary industry that is oriented towards exchange rates that can fulfil individual and social needs such as lifestyle. Then the food processing is adapted to business interests, so that a culinary art that is produced is no longer based on the ability or quality and uniqueness or characteristics of a culinary, but is changed to become a market interest(Sunar, in Journal Gastronomy Indonesia Volume 5, 2017). According to Diah Satari (2016) this transformation makes local food in a different dimension and often adjusted to the tastes of tourists but without change its authenticity. Not all aspects of Balinese culinary are relevant by maintaining the "authenticity" of the culinary. Transformation can be done by replacing some of the more versatile ingredients accepted for tourists and using modern technology to improving sanitation conditions.

\section{CONCLUSION}

Based on the result of analysis and based on a study that has done, it generates some conclusions that four samples from the seller and has been tested in the laboratory using Chromatography test is negative contain artificial colour. KembangGoyang in market positive use natural dyes, this can be een based on the results of laboratory tests that have been done at the UPT Analytical Laboratory of the Faculty of Marine and Fisheries, Udayana University, Bukit -Jimbaran, It has produced negative data or there is no content of synthetic dyes contained in samples of KembangGoyang snacks which sell in Karangsokong traditional market, Karangasem Commodification in Kembang Goyang significantly gives an impact to raise the economic value as a tourism product. It has been proved by KembangGoyang selling, in average the seller can get income Rp. 195.833 which is the buyer is the tourists who visit Subagan Village. Also, on a special day, the selling of Kembang Goyang is higher than the average day worth of Rp.947.517. The additional colour that has given to KembangGoyang can give the appearance of Kembang Goyang more attractive. It is not only commodification on the aesthetic aspect of Kembang Goyang, but the Safety Aspect would be the crucial aspect that has to be considered.

Consumers do not need to hesitate to buy coloured Kembang Goyang snacks that sell in Subagan village, because these snacks are safe for consumption and use natural colouring ingredients. However, consumers must remain to be careful and wise on choosing food; consumers have to know well the characteristics and differences in foods which one use natural and artificial dyes to prevent health problems due to consuming foods that contain synthetic dyes that are very dangerous. 


\section{REFERENCES}

Anantara, Ida Bagus Made Yoga. 2013. Tinjauan Penggunaan Jenis Zat Pewarna Pada Rainbow Cake di Toko Kue Kawasan Jalan Surapati Denpasar Bali. Skripsi tidak diterbitkan. Bali : STP Nusa Dua

Azmiyawati, Choiril. 2007. Zat KimiaBerbahaya Dalam Makanan dan Minuman.Jakarta : PT. Sunda Kelapa Pustaka Badan POM. 2006. Bahan Berbahaya yang DilaranguntukPangan. http://www.pom.go.id/mobile/in dex.php/view/berita/139/BAHAN-BERBAHAYAYANGDILARANG-UNTUKPANGAN.html, diakses 21 Mei 2018)

Cahyadi, Wisnu. 2009. Analisis danAspek Kesehatan Bahan Tambahan Pangan. Jakarta : PT. BumiAksara Cakrawati, Dewi.,danMustika. 2012. Bahan Pangan, Gizi, dan Kesehatan. Bandung :AlFABETA

Sastri, Diah.2016. Inovasi Dalam ompetisi: Usaha Kuliner Lokal menciptakan Keunggulan Kompetitif Ubud. Jurnal Mahasiswa Pariwisata: Universitas Udayana.

Fuadah, Indri Elma. 2016. Pengaruh Penambahan Tepung Bekatul Terhadap Mutu Organoleptik Kue Kembang Goyang. EJournal Boga, 5(3),18-26 Isminingsih. 1978. Pengantar Kimia ZatWarna. Bandung: STTT Kompas.2017. Zat Pewarna Tekstil Masih Ditemukan pada JajananPasar di Bali. (https://regional.kompas.com/read/2017/04/03/1101005 1/zat.pewarna.tekstil.masih.ditemukan.pada.jajanan.pas ar.di.bali, diakses 03 Mei 2018)

KUDPF. 2017. Dasar Teori Kromatografi. (https://kupdf.com/download/dasarteorikromatografi_59d3c37b08bbc59 a53687207_pdf, diakses 20 Mei 2018)

Nasution, AnnisSyarifah. 2014. Kandungan Zat Pewarna Sintetispada Makanan dan Minuman Jajanan di SDN I$X$ Kelurahan Ciputat Kecamatan Ciputat Kota Tanggerang Selatan.Skripsi.Jakarta : UIN SyarifHidayatullah Jakarta Nugraheni, Mutiara. 2014. PewarnaAlami: Sumber dan Aplikasinya Pada Makanan dan Kesehatan. Yogyakarta :GrahaIlmu

Putra, DewabGedeWijaya. 2017. Tinjauan Jenis-Jenis Pewarna yang Dipakai dalam Es Daluman yang dijual di Pasar Kediri Tabanan Bali. Skripsi tidak diterbitkan.Bali : STP Nusa Dua

Riadussolihin, Muhammad. 2016. Tinjauan Kandungan Pemanis pada Kleponsebagai Jajanan Tradisional yang Dijual di Pasar Badung Kota Denpasar.Skripsitidakditerbitkan .Bali : STP Nusa Dua

Sugiyatmi, Sri. 2006. AnalisisFaktorfaktor Risiko Pencemaran Bahan Toksik Boraks dan Pewarna Pada Makanan Jajanan Tradisional yang Dijual di Pasar-pasar Kota Semarang.Tesis.Semarang :UniversitasDiponegoro

Sugiyono. 2005. MemahamiPenelitianKuantitatif. Bandung :Alfabeta SumahendraI PutuAgus. 2018. KelurahanSubagan. (http://www.kelsubagan. go.iddiakses 03 Mei 2018)

Sumaryani, Komang.,PutuAgustini, dan Nanak Antarini. 2014. Identifikasi Rhodamin B pada Jajan Kembang Goyang dan Jajan Sirat di Desa Pekutatan Kabupaten
Jembrana. JurnallimuGizi, 5(1), 44-51 Sora.2015. Pengertian Jajanan Pasar dan Beberapa Contohnya. (http://www.pengertianku.net/2015/04/inilahpengertian-jajananpasar. html, diakses 21 Mei 2018)

Sunar.2017. Komodifikasi Gudeg Yogyakarta dan Pengembangan Dalam Industri Pariwisata. Jurnal Gastronomy Indonesia. OJS Sekolah Tinggi Pariwisata Nusa Dua Bali.

Warsito, Heri.,Rindiani., danFafaNurdyansyah. 2015. Ilmu Bahan Makanan Dasar. Yogyakarta: NuhaMedika Wikipedia. 2014. Kue Kembang Goyang. (https://id.wikipedia.org/wiki/Kue_kembang_goyang, diakses 20 Mei 2018)

Yahyono, Sufi S. 1996. Jajandan Kue Tradisional Indonesia. (http://www.bukabuku.com, diakses 21 Mei 2018) 